\title{
Poinsettia Developmental and Postproduction Responses to Growth Retardants and Irradiance
}

\author{
Douglas A. Bailey' and William B. Miller \\ Department of Plant Sciences, University of Arizona, Tucson, AZ 85721
}

Additional index words. Euphorbia pulcherrima, chlormequat chloride, daminozide, light, uniconazole, paclobutrazol

\begin{abstract}
Plants of Euphorbia pulcherrima Wind. 'Glory' were grown under total irradiances of $13.4,8.5$, or $4.0 \mathrm{~mol} \cdot \mathrm{m}^{-2} \cdot \mathrm{day}^{-1}$ and sprayed with water (control), 2500 mg daminozide/liter $+1500 \mathrm{mg}$ chlormequat chloride/liter $(\mathrm{D}+\mathrm{C}), 62.5 \mathrm{mg}$ paclobutrazol/liter, or $4,8,12$, or $16 \mathrm{mg}$ uniconazole/liter to ascertain plant developmental and postproduction responses to treatment combinations. Anthesis was delayed for plants grown under the lowest irradiance. Anthesis was delayed by the $D+C$ treatment, whereas other growth retardant treatments had no effect on anthesis date. Irradiance did not affect plant height at anthesis, but all growth retardant treatments decreased height over control plants. Inflorescence and bract canopy diameters were decreased at the lowest irradiance level. Growth retardants did not affect individual inflorescence diameters, but all, except paclobutrazol and 4 and $8 \mathrm{mg}$ uniconazole/ liter, reduced bract canopy diameter compared with control plants. Plants grown under the lowest irradiance developed fewer inflorescences per plant and fewer cyathia per inflorescence. Cyathia abscission during a 30-day postanthesis evaluation increased as irradiance was decreased; cyathia abscission was unaffected by growth retardant treatment. Leaf abscission after 30 days postanthesis was lowest for plants grown under the lowest irradiance. At 30 days postanthesis, all growth retardant treatments increased leaf abscission over controls. Results indicate that irradiance and growth retardant treatments during production can affect poinsettia crop timing, plant quality at maturity, and subsequent postproduction performance. Chemical names used: 2-chloroethyl-N,N,N-trimethylammonium chloride (chlormequat chloride); butanedioic acid mono (2,2-dimethyl hydrazide) (daminozide); $\beta$-[(4-chlorophenyl) methyl]- $\alpha$-(1,1-dimethylethyl)-1H-1,2,4-triazole-1-ethanol (paclobutrazol), (E)-1-(p-chlorophenyl)-4,4-dimethyl2-(1,2,4-triazol-1-yl)-l-penten-3-ol (uniconazole, XE-1019).
\end{abstract}

Crop timing, plant quality at sale, and postproduction performance of poinsettias have increased in importance as expanding markets require longer shipping times and as the holiday sales season has become extended. Many production factors including nutrition (Staby and Kofranek, 1979), temperature (Miller and Heins, 1986), irradiance (Marousky and Shanks, 1966; Nell and Barrett, 1986; Staby and Kofranek, 1979), plant spacing (Miller and Heins, 1986), time of harvest (Marousky and Shanks, 1966), and duration of postharvest storage (Scott et al., 1982) have been evaluated as to their effects on poinsettia plant quality at sale and after placement into interior environments. One

\footnotetext{
Received for publication 6 Dec. 1990. Appreciation is extended to Paul Ecke Poinsettias, Encinitas, Calif., for donating the poinsettias, to Valent Corp., Fresno, Calif., for financial support, and to Larry J. Kaspersen for technical assistance throughout this project. The cost of publishing this paper was defrayed in part by the payment of page charges. Under postal regulations, this paper therefore must be hereby marked advertisement solely to indicate this fact.

'Current address: Dept. of Horticultural Science, North Carolina State Univ., Box 7609, Raleigh, NC 27695-7609.

'Current address: Dept. of Horticulture, Clemson Univ., Clemson, SC 29634
}

production factor that has not been fully investigated is the effect of chemical growth retardants. High doses of chlormequat chloride can decrease leaf retention after placement in an interior environment (Marousky and Shanks, 1966); however, little is known about the effects of recently introduced chemical growth retardant treatments on poinsettias. Therefore, the objective of this -study was to examine the effects of currently employed (daminozide + chlormequat chloride and paclobutrazol foliar sprays) and future (uniconazole foliar sprays) plant growth regulator treatments on crop timing, crop quality at harvest, and postproduction performance in an interior environment.

Rooted cuttings of poinsettia 'Gutbier V14 Glory' were potted, one per 1.3-liter (15 cm-diameter) plastic pot, on 30 Aug. 1989 and placed at a $38 \times 38 \mathrm{~cm}$ spacing in a $26 /$ $18 \mathrm{C}$ (venting set point/night set point temperatures) double layer polyethylene greenhouse covered with $70 \%$ transmittance shade cloth. The root substrate consisted of 1 sandy loam soil :2 sphagnum peat :2 perlite (by volume) mixture amended with $890 \mathrm{~g}$ treble superphosphate, $593 \mathrm{~g} \mathrm{KNO}_{3}, 1187 \mathrm{~g}$ $\mathrm{MgSO}_{4} \cdot 7 \mathrm{H}_{2} 0,1780 \mathrm{~g} \mathrm{CaSO}_{4} \cdot 2 \mathrm{H}_{2} 0$, and 74 g Frit Industries Trace Elements no. 555 (Peters Fertilizer Products, Grace-Sierra, Fogelsville, Pa.) per cubic meter. The plants were fertilized at each watering with $300 \mathrm{mg}$ each of $\mathrm{N}$ and $\mathrm{K} /$ liter supplied from $776 \mathrm{mg}$

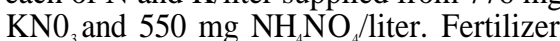
solution was maintained at $6.0 \mathrm{pH}$ by injecting $75 \%(\mathrm{w} / \mathrm{w})$ technical grade $\mathrm{H}_{3} \mathrm{PO}_{4}$ into the system, which supplied $37 \mathrm{mg} \mathrm{P} /$ /iter at every watering. Vegetative growth was maintained by the use of incandescent light from 1600 to $2400 \mathrm{HR}$ daily starting 5 Sept. 1989. Natural short days were started on 4 Oct. 1989 and maintained throughout the remainder of the experiment. The temperature was monitored constantly throughout experimentation using LI-COR LI-1000-16 Temperature Sensors connected to a LI-COR LI1000 Data Logger (LI-COR, Inc., Lincoln, Neb.). Ambient temperature averaged $( \pm \mathrm{SD})$ $25 \pm 2 \mathrm{C}$ day $(0601-1800 \mathrm{HR})$ and $19 \pm 3 \mathrm{C}$ night (1801-0600 HR) during the course of the experiment. Photosynthetic photon flux (PPF) was monitored throughout experimentation using LI-COR LI-190SA Quantum Sensors connected to a LI-COR LI-1000 Data Logger; PPF averaged $15.2 \pm 4$ $\mathrm{mol} \cdot \mathrm{m}^{-2} \cdot \mathrm{day}^{-1}$ from time of potting to the start of irradiance treatments, coincident with pinch date. Plants were pinched, leaving five nodes per plant on 13 Sept. 1989 and placed under ambient irradiance, $\sim 70 \%$ or $\sim 33 \%$ of ambient irradiance. All growth retardant applications were made on 27 Sept. 1989 by spraying $204 \mathrm{ml}$ of solution evenly over 1 $\mathrm{m}^{2}$ of bench area, and each pot received $\sim 7.1$ $\mathrm{ml}$ of spray. At this time, plants averaged $21 \pm 2 \mathrm{~cm}$ and $4 \pm 1 \mathrm{~cm}$ in diameter and height, respectively, and newly developed shoots averaged $5.3 \pm 1 \mathrm{~cm}$ in length.

Plant height (measured from the top rim of the pot to the top of the bract canopy display), number of inflorescences, inflorescence diameter of the two most acropetal inflorescences, diameter of the plant bract canopy display, number of aborted/senesced cyathia, number of remaining cyathia, and days to anthesis from start of short days were recorded for each for each plant at anthesis. Anthesis was defined as the time when pollen was first shed by cyathia. At anthesis, each plant was placed into an interior environment for postproduction performance evaluation. The postproduction evaluation room averaged $20 \pm 1 \mathrm{C}$ day (0801-1600 $\mathrm{HR})$ and $19 \pm 1 \mathrm{C}$ night (1601-0800 HR), and relative humidity averaged $32 \% \pm 3 \%$. Lights were kept on from 0800-1600 HR, and irradiance at plant canopy height averaged $0.27 \pm 0.07 \mathrm{~mol} \cdot \mathrm{m}^{-2} \cdot \mathrm{day}^{-1}$. Upon placement in the postproduction environment, cyathia drop was recorded daily for each plant for 30 days. On day 30, leaf abscission was recorded for each plant.

The experiment was conducted using a replicated split-plot design, with irradiance as the main plot (three levels; $13.4 \pm 3.9$, $8.5 \pm 2.5$, and $\left.4.0 \pm 1.4 \mathrm{~mol} \cdot \mathrm{m}^{-2} \cdot \mathrm{day}^{-1}\right)$ and growth regulator as the subplot [seven treatments; foliar sprays of water (control); $2500 \mathrm{mg}$ daminozide/liter $+1500 \mathrm{mg}$ chlormequat chloride/liter $(\mathrm{D}+\mathrm{C}) ; 62.5 \mathrm{mg} \mathrm{pac}-$ lobutrazol/liter; or $4,8,12$, or $16 \mathrm{mg}$ uniconazole/fiter] with three replications and three plants per experimental unit. Data were tested using analysis of variance. Statistical 
Table 1. Effects of irradiance and selected growth retardant treatments on 'V-14 Glory' poinsettias at anthesis and 30 days after anthesis.'

\begin{tabular}{|c|c|c|c|c|c|c|c|c|}
\hline Treatment & $\begin{array}{l}\text { Days to } \\
\text { anthesis }\end{array}$ & $\begin{array}{l}\mathrm{Ht} \text { at } \\
\text { anthesis } \\
(\mathrm{cm})^{y}\end{array}$ & $\begin{array}{l}\text { Inflorescences/plant } \\
\text { (no.) }\end{array}$ & $\begin{array}{l}\text { Diam of } \\
\text { top } \\
\text { inflorescence } \\
\text { (cm) }\end{array}$ & $\begin{array}{c}\text { Bract } \\
\text { canopy } \\
\text { diam } \\
(\mathrm{cm})\end{array}$ & $\begin{array}{l}\text { Cyathia } \\
\text { at } \\
\text { anthesis } \\
\text { (no.) }\end{array}$ & $\begin{array}{l}\text { Cyathia } \\
\text { loss } \\
\text { after } 30 \\
\text { days }(\%)\end{array}$ & $\begin{array}{c}\text { Abscised } \\
\text { leaves } \\
\text { after } 30 \text { days } \\
\text { (no.) }\end{array}$ \\
\hline \multicolumn{9}{|l|}{$\begin{array}{l}\text { Irradiance } \\
\qquad\left(\mathrm{mol} \cdot \mathrm{m}^{-2} \cdot \mathrm{day}^{-1}\right)\end{array}$} \\
\hline $13.4 \pm 3.9$ & $60 \mathrm{~A}^{\mathrm{w}}$ & 22 & $4.9 \mathrm{~b}$ & $32 \mathrm{~B}$ & $41 \mathrm{~b}$ & $16 \mathrm{~B}$ & $12 \mathrm{a}$ & $27 \mathrm{~B}$ \\
\hline $8.5 \pm 2.5$ & $60 \mathrm{~A}$ & 23 & $4.9 \mathrm{~b}$ & $30 \mathrm{AB}$ & $42 \mathrm{~b}$ & $15 \mathrm{AB}$ & $22 \mathrm{~b}$ & $27 \mathrm{~B}$ \\
\hline $4.0 \pm 1.4$ & $66 \mathrm{~B}$ & 23 & $4.5 \mathrm{a}$ & $29 \mathrm{~A}$ & 38 a & $13 \mathrm{~A}$ & $27 \mathrm{~b}$ & $11 \mathrm{~A}$ \\
\hline \multicolumn{9}{|l|}{$\begin{array}{l}\text { Growth retardant } \\
\left(\mathrm{mg} \cdot \text { liter }^{-1}\right)\end{array}$} \\
\hline Control (water) & $61 \mathrm{~A}$ & $26 \mathrm{D}$ & 4.7 & 32 & $42 \mathrm{C}$ & 16 & 17 & $15 \mathrm{~A}$ \\
\hline $2500 \mathrm{D}+1500 \mathrm{C}^{\mathrm{V}}$ & $64 \mathrm{~B}$ & $23 \mathrm{BC}$ & 4.7 & 30 & $38 \mathrm{~A}$ & 15 & 20 & $28 \mathrm{C}$ \\
\hline Paclobutrazol 62.5 & $61 \mathrm{~A}$ & $23 \mathrm{BC}$ & 5.0 & 30 & $41 \mathrm{BC}$ & 15 & 17 & $23 \mathrm{BC}$ \\
\hline Uniconazole 4 & $61 \mathrm{~A}$ & $24 \mathrm{C}$ & 4.8 & 30 & $42 \mathrm{C}$ & 15 & 22 & $23 \mathrm{BC}$ \\
\hline 8 & $61 \mathrm{~A}$ & $21 \mathrm{AB}$ & 4.7 & 30 & $40 \mathrm{ABC}$ & 15 & 15 & $21 \mathrm{~B}$ \\
\hline 12 & $61 \mathrm{~A}$ & $21 \mathrm{AB}$ & 4.8 & 30 & $39 \mathrm{AB}$ & 14 & 22 & $21 \mathrm{~B}$ \\
\hline 16 & $62 \mathrm{~A}$ & $20 \mathrm{~A}$ & 4.7 & 30 & $38 \mathrm{AB}$ & 14 & 23 & $21 \mathrm{~B}$ \\
\hline \multicolumn{9}{|l|}{ ANOVA } \\
\hline Irradiance & $* *$ & NS & $*$ & ** & * & $*$ & $*$ & $*$ \\
\hline Growth retardant & $*$ & $* * *$ & NS & NS & $* * *$ & NS & NS & $* * *$ \\
\hline Irr $\times$ growth retardant & NS & NS & NS & NS & NS & NS & NS & NS \\
\hline
\end{tabular}

${ }^{\mathrm{z}}$ All data based on three replications, three plants per replicate.

yeasured from the soil surface to the top of the bract canopy.

${ }^{\times}$Number of cyathia produced in the most acropetal inflorescence; recorded at anthesis.

"Mean separations within columns for irradiance and growth retardant by LSD, 5\% (lowercase letters) level or $1 \%$ (uppercase letters) level.

${ }^{\vee} \mathrm{D}=$ daminozide and $\mathrm{C}=$ chlormequat chloride.

$\mathrm{Ns}, *, * *, * * * \mathrm{~F}$ test of factor nonsignificant or significant at $0.05 \geq \alpha>0.01,0.01 \geq \alpha>0.001$, or at $\alpha \leq 0.001$, respectively.

analyses were conducted using PROC GLM in SAS 6.03 (SAS Institute, Inc. Cary, N.C.).

Anthesis was delayed 6 days for plants grown under $4 \mathrm{~mol} \cdot \mathrm{m}^{-2} \cdot$ day $^{-1}$ compared with plants grown under 13.4 or 8.5 $\mathrm{mol} \cdot \mathrm{m}^{-2} \cdot \operatorname{day}^{-1}($ Table 1$)$. The D + C treatment delayed anthesis an average of 3 days compared with water-sprayed controls; no other growth retardant treatment significantly affected date of anthesis. Irradiance appeared to be the more important factor in crop timing, with lower light delaying anthesis. There was no irradiance $\times$ growth retardant interaction for anthesis or any of the other data measured.

Irradiance did not affect plant height at anthesis, but all growth retardant treatments resulted in shorter plants than the controls (Table 1). Plant height did not increase at lower irradiances, unlike noted by Staby and Kofranek (1979). Because our plants were spaced at $38 \times 38 \mathrm{~cm}$, excessive elongation due to overcrowding and limited irradiance appeared to be absent. However, the inflorescence count was reduced under the lowest irradiance, thus limiting marketable value of the plants. The number of inflorescences per plant and diameter of the top (most acropetal) inflorescence were unaffected by growth retardant treatments. Diameter of the top inflorescence decreased as irradiance was decreased. The second-most acropetal inflorescence responded identically to irradiance and growth retardants (data not shown). Bract canopy diameter was less for plants grown under $4 \mathrm{~mol} \cdot \mathrm{m}^{-2} \cdot$ day $^{-1}$ than under high irradiances and was significantly decreased by all growth retardant treatments except paclobutrazol at $62.5 \mathrm{mg} \cdot \mathrm{liter}^{-1}$ and uniconazole at 4 and $8 \mathrm{mg} \cdot$ liter $^{-1}$. The $\mathrm{D}+\mathrm{C}$ and the $16 \mathrm{mg}$ uniconazole/liter treatments resulted in equally small bract canopy diameters. Inflorescence diameter and plant bract canopy diameter reductions are undesirable, resulting in less visual impact per plant and, subsequently, lower plant quality.

The number of aborted or abscised cyathia at anthesis was unaffected by treatments and averaged $0.15 \pm 0.7$ for all plants (data not shown). The number of cyathia developed by the top inflorescence (recorded at anthesis; equals number of intact cyathia + number of aborted cyathia) was decreased by the lowest irradiance level, but was unaffected by growth retardant treatments (Table 1). Although the degree of premature cyathia abscission was not increased by lower light levels as previously reported (Miller and Heins, 1986), cyathia production was reduced with reduced irradiance. Fewer cyathia, whether a result of abscission or from decreased cyathia development, is undesirable and can result in significant reductions in crop quality and market value (Miller and Heins, 1986).

Cyathia abscission during the 30 -day postanthesis evaluation was increased by the two lowest irradiance levels during production but was not significantly affected by growth retardant treatments. The increase in cyathia abscission in combination with fewer cyathia developed on plants grown in low irradiance resulted in a lower quality product for the end consumer. However, plants grown under the lowest irradiance had the least postanthesis leaf abscission, similar to results of previous studies (Miller and Heins, 1986; Nell and Barrett, 1986). Nell and Barrett (1986) showed increased leaf retention of poinsettias by reducing irradiance for only the last 3 weeks of production without increasing cyathia abscission, as we observed, on plants grown under lower irradiance throughout the entire production period.
Therefore, the critical period to maintain high light levels for cyathia development and subsequent retention appears to be from time of pinch to 3 weeks preanthesis. During the last 3 weeks of production, a reduction in irradiance may be desirable for postproduction leaf retention.

Growth retardant treatments increased leaf abscission under interior conditions compared with controls. Abscission was highest on plants treated with $\mathrm{D}+\mathrm{C}$ but similar to that sustained with paclobutrazol or uniconazole at $4 \mathrm{mg} \cdot$ liter $^{-1}$. Marousky and Shanks (1966) also reported that chlormequat chloride detrimentally affected postanthesis leaf retention. Although $62.5 \mathrm{mg}$ paclobutrazol/ liter increased leaf abscission over controls, uniconazole-treated plants (4 to $12 \mathrm{mg} \cdot$ liter $^{-1}$ ) had significantly less leaf loss than plants sprayed with D + C. If chemical height control is needed, paclobutrazol or uniconazole may be more desirable than $\mathrm{D}+\mathrm{C}$ with respect to postanthesis leaf retention.

It is not known if reducing irradiance during the last 3 weeks of production would help alleviate increased leaf drop caused by growth retardant treatments. Nell and Barrett (1986) drenched all plants with chlormequat chloride in their irradiance acclimation experiment but had no nondrenched plants as controls. Future studies are needed to examine the interaction of growth retardant treatments with irradiance acclimation treatments for postanthesis quality maintenance.

\section{Literature Cited}

Marousky, F.J. and J.B. Shanks. 1966. Effects of environmental factors and plant maturity on bract and leaf abscission in Euphorbia pulcherrima Wind. Proc. Amer. Soc. Hort. Sci. 88:662670.

Miller, S.H. and R.D. Heins. 1986. Factors in- 
fluencing premature cyathia abscission in poinsettia 'Annette Hegg Dark Red'. J. Amer. Sot. Hort. Sci. 111:114-121.

Nell, T.A. and J.E. Barrett. 1986. Production light level effects on light compensation point, car- bon exchange rate and post-production longevity of poinsettias. Acts Hort. 181:257-262.

Scott, L. F., T.M. Blessington, and T.A. Price 1982. Postharvest performance of poinsettia as affected by micronutrient source, storage and cultivar. HortScience 17:901-902.

Staby, G.L. and A.M. Kofranek. 1979. Production conditions as they affect harvest and postharvest characteristics of poinsettias. J. Amer. Soc. Hort. Sci. 104:88-92. 